\title{
PENINGKATAN HASIL BELAJAR DENGAN MENGOPTIMALKAN METODE EKSPOSITORI PADA MATA PELAJARAN MATEMATIKA KELAS VIII SMP
}

\author{
Melisa Vivitri ${ }^{1)}$, Sunardi $^{2)}$ \\ ${ }^{1)}$ Guru SMP Muhammadiyah 4 Palembang, ${ }^{2)}$ Program Studi Pendidikan Matematika Fakultas \\ Keguruan dan Ilmu Pendidikan Universitas Muhammadiyah Palembang \\ 1)email: melisavivitri@yahoo.co.id \\ ${ }^{2)}$ email : Sunardi_hek@yahoo.co.id
}

\begin{abstract}
The problem in this study is the student learning outcomes on the subject matter of relations and functions, straight-line equations, linear equations are still less than the completeness criteria determined by school students that is 80 . The subjects of this study were students of class VIII SMP Muhammadiyah 4 Palembang. The number of students is 32 people consisting of 16 men and 16 women. The learning method used is expository. After observing 2 times the implementation of learning as a pre-cycle action in class by the teacher and discussed with the lecturer the results have not yet reached the Minimum Mastery Criteria (KKM), there are stages that have not yet appeared according to syntax, and need student involvement. This research optimizes the expository method through discussion and collaboration between teachers and lecturers. Learning in cycles 1 and 2 using the expository method of student learning outcomes exceed the KKM targets that have been set. The use of expository methods is very good, seen from the increase in students' mastery learning, student enthusiasm and student involvement in participating in the learning process.
\end{abstract}

Keywords : expository, mathematics, learning outcomes

\begin{abstract}
Abstrak
Masalah dalam penelitian ini adalah hasil belajar siswa pada materi pokok relasi dan fungsi, persamaan garis lurus, persamaan linier masih kurang dari kriteria ketuntasan siswa yang ditentukan sekolah yaitu 80. Subjek Penelitian ini adalah peserta didik kelas VIII SMP Muhammadiyah 4 Palembang. Adapun jumlah siswanya adalah 32 orang yang terdiri dari 16 laki-laki dan 16 perempuan. Metode pembelajaran yang digunakan adalah ekspositori. Setelah dilakukan pengamatan 2 kali pelaksanaan pembelajaran sebagai tindakan prasiklus di kelas oleh guru dan didiskusikan dengan dosen hasilnya nilai belum mencapai Kriteria Ketuntasan Minimal (KKM), ada tahapan yang belum muncul sesuai sintak, dan perlu keterlibatan siswa. Penelitian ini mengoptimalkan metode ekspositori melalui diskusi dan kolaborasi antara guru dan dosen. Pembelajaran pada siklus 1 dan 2 menggunakan motode ekspositori hasil belajar siswa melampaui target KKM yang sudah ditetapkan. Penggunaan metode ekspositori sangat baik, terlihat dari kenaikan ketuntasan belajar siswa, antusiasme siswa dan keterlibatan siswa dalam mengikuti proses pembelajaran.
\end{abstract}

Kata kunci : ekspositori, matematika, hasil belajar

OPendidikan Matematika UIN Raden Fatah Palembang 


\section{PENDAHULUAN}

Matematika sebagai wahana ilmu pengetahuan memegang peranan penting dalam pendidikan. Mempelajari matematika merupakan salah satu sarana berpikir ilmiah dan logis serta mempunyai peranan penting dalam upaya peningkatan kualitas sumber daya manusia. Mengingat pentingnya matematika sebagai ilmu dasar, maka pembelajaran matematika diberbagai jenjang pendidikan formal perlu mendapat perhatian yang serius. Menurut (Suryadi, 2013) dua aspek yang mendasar dalam proses pembelajaran matematika yaitu hubungan siswa dengan materi dan hubungan siswa dengan guru ternyata dapat menciptakan suatu situasi didaktis dan pedagogik yang tidak sederhana bahkan sering terjadi sangat kompleks. Mata pelajaran matematika perlu diberikan kepada semua peserta didik untuk membekali mereka dengan kemampuan berpikir logis, analitis, sistematis, kritis dan kreatif serta kemampuan bekerja sama. Karena dengan belajar matematika, kita akan belajar bernalar secara kritis, kreatif dan aktif.

Salah satu topik matematika untuk SMP yang harus dikuasai adalah konsep aljabar. Aljabar merupakan bahasa simbul dan relasi aljabar yang dikenalkan oleh Al Khawarizmi pada abad ke-9 dipandang sebagai ilmu persamaan yang dapat digunakan sebagai alat untuk memecahkan masalah sehari-hari (Kieran, 2004). Untuk mempelajari topik aljabar diperlukan suatu proses yang baik dan benar selama pembelajaran yang diakhiri dengan tes akhir dalam bentuk tes atau tugas. Dalam banyak kasus, tes hanya berorientasi pada pencapaian hasil belajar dan tidak mempertimbangkan proses belajar. Bagaimana proses siswa dalam mencapai hasil belajar, memperhatikan, berlatih, meragakan bimbingan belajar bukan jadi perhatian (Sunardi, 2013). Metode mengajar banyak jenisnya yang harus disesuaikan dengan materi pokok yang akan diajarkan. Penggunaan suatu metode haruslah konsisten dan runtut sesuai dengan sintak yang dibuat sebagai panduan.

Startegi ekspositori adalah strategi pembelajaran yang memadukan metode ceramah, tanya jawab, dan peragaan demonstrasi (Atriyanto \& Sulistiyo, 2014). Metode ekspositori adalah metode yang digunakan guru dalam mengajar keseluruhan konsep, fakta dan aturan-aturan matematika kepada siswa, sedangkan siswa mendengarkan dan bertanya apabila tidak mengerti yang telah diterangkan oleh guru. Dari uraian di atas, metode ekspositori lebih menekankan kepada proses berstuktur, maka peneliti mempunyai alternatif dalam pemecahan masalah yaitu mengoptimalkan metode ekspositori dalam pembelajaran materi persamaan garis lurus dan persamaan linier dua variabel. Tujuan 
penelitian ini dilakukan untuk melihat apakah dalam mengoptimalkan model pembelajaran ekspositori dapat meningkatkan hasil belajar siswa.

\section{METODE PENELITIAN}

Penelitian ini menggunakan pendekatan kualitatif dengan analisis data berupa deskripsi dari hasil pengumpulan data. Jenis penelitian ini adalah Penelitian Tindakan Kelas (PTK) yang bertujuan untuk melakukan peningkatan hasil belajar siswa. Pembelajaran dalam penelitian ini dilakukan menggunakan beberapa siklus, dengan mengoptimalkan metode ekspositori. Subjek Penelitian adalah peserta didik kelas VIII SMP Muhammadiyah 4 Palembang. Adapun jumlah siswa adalah 32 orang yang terdiri dari 16 laki-laki dan 16 perempuan. Penelitian tindakan kelas merupakan suatu pencermatan terhadap kegiatan yang sengaja dimunculkan dan terjadi di dalam sebuah kelas (Arikunto, 2013). Penelitian Tindakan kelas adalah penelitian yang dilakukan dengan tujuan memperbaiki mutu praktek pembelajaran di kelas. Tujuan utama PTK adalah untuk memecahkan masalah nyata yang terjadi di kelas dan meningkatkan kegiatan nyata guru dalam kegiatan pengembangan profesinya (Kunandar, 2011).

Sumber data dari penelitian ini adalah hasil tes siswa yang diberikan oleh peneliti setelah akhir siklus. Tes adalah serentetan pertanyaan atau latihan serta alat lain yang digunakan untuk mengukur keterampilan, pengetahuan inteligensi, kemampuan atau bakat yang dimiliki oleh individu atau kelompok (Arikunto 2010:193). Menurut Sunardi (2013:51) tes didefinisikan sebagai perangkat pertanyaan atau tugas yang direncanakan untuk memperoleh informasi tentang kemampuan yang sudah diperoleh dari suatu proses pembelajaran dalam pendidikan, menggunakan butir-butir pertanyaan yang mempunyai jawaban atau ketentuan yang dianggap benar. 
Urutan siklus penelitian tindakan menggunakan prosedur PTK menurut Kemmis dan McTaggart sebagai berikut:

\section{SIKLUS PELAKSANAAN PTK}

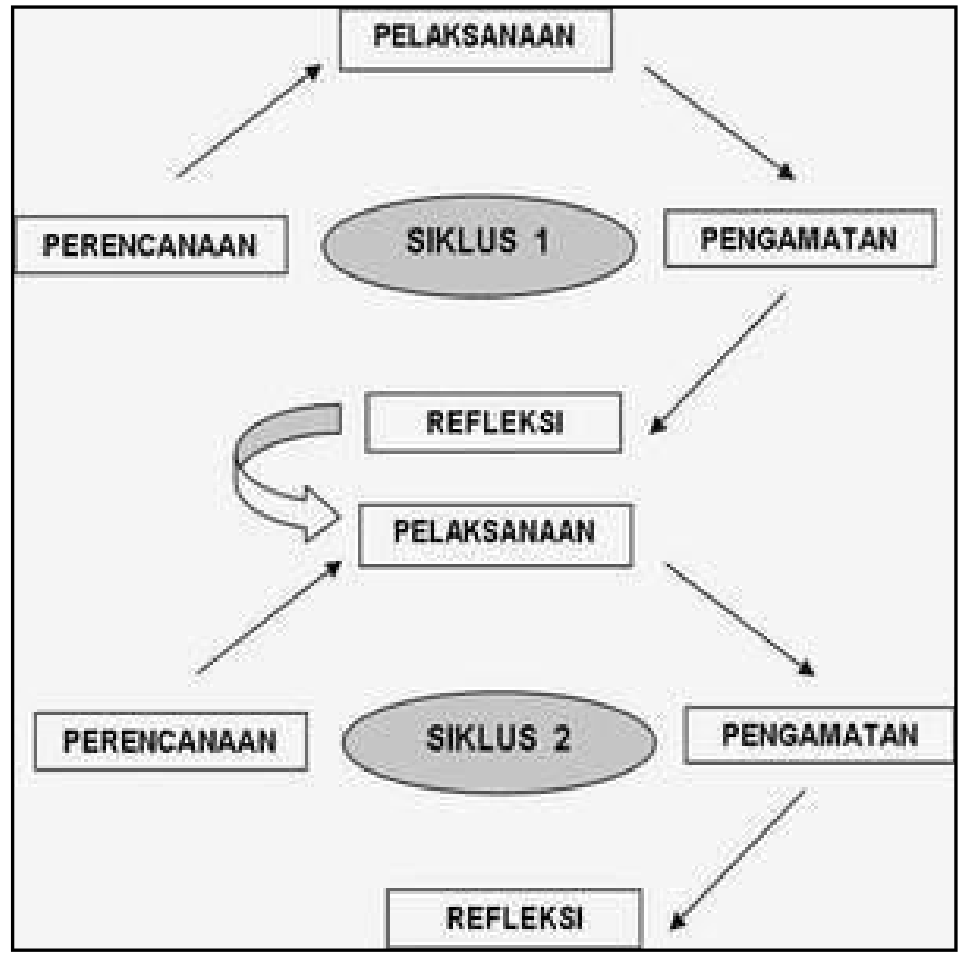

\section{Gambar 1. Prosedur PTK menurut Kemmis dan McTaggart (Arikunto 2010:137)}

Langkah-langkah pembelajaran metode ekspositori yang dilakukan peneliti: (1) persiapan, (2) penyajian, (3) korelasi, (4) menyimpulkan, (5) aplikasi. Langkah-langkah pembelajaan tersebut dituangkan dalam RPP dan lembar observasi yang telah disepakati untuk digunakan dan diamati pada saat pembelajaran pelaksanaannya. Prosedur perbaikan pembelajaran dari guru matematika dan dosen sekolah dimulai dari perencanaan dengan mempersiapkan rencana pembelajaran menggunakan metode ekspositori, menyiapkan lebar obervasi dan soal latihan, selanjutnya melaksanakan pembelajaran materi relasi dan fungsi oleh guru matematika. Kegiatan pembelajaran yang dilakukan oleh guru pada materi relasi dan fungsi disebut kegiatan pra siklus, hasil dari tes akhir materi dan pengamatan dosen selama pembelajaran dijadikan dasar untuk perbaikan. Pembelajaran pra siklus didapat proses pembelajaran tidak sesuai dengan langkah pembelajaran terutama kegiatan kelompok tiap kelompok 2 orang sulit memantau atau mengelola kelas maka di ubah 
pada materi fungsi menjadi tiap kelompok 4 orang hasil diskusinya berjalan baik tetapi masih ada indikator pembelajaran menggunakan metode ekspositori.

Pertemuan berikutnya adalah pelaksanaan siklus 1 pembelajaran dilakukan sesuai dengan perencanaan yaitu kelompok diskusi anggotanya 4 orang, penyampaian materi sesuai dengan rencana pelaksanaan pembelajaran, membagi perhatian kepada siswa memberikan motivasi, kolaborasi antara siswa dan guru, mengkomunikasikan, menyimpulkan dan mengkomunikasikan. Kemudian mengumpulkan data, pengumpulan data yang dilakukan adalah berbentuk tes, tes yang dilakukan peneliti yaitu berupa tes akhir yang dilakukan dengan tujuan melihat pemahaman siswa dan hasil belajar siswa terhadap materi persamaan garis lurus. Kemudian merefleksi dari bantuan dosen sekolah dengan menganalisis hasil pembelajaran yang telah dicatat.

Penelitian ini dikatakan berhasil apabila telah memenuhi kriteria keberhasilan tiap siklus yaitu: 1) Hasil belajar dikatakan memenuhi indikator keberhasilan siklus apabila hasil tes terdapat $75 \%$ siswa memperoleh nilai $\geq 80$ dan 2) Proses pembelajaran dengan menerapkan metode ekspositori yang dimodifikasi dikatakan baik apabila diskriptor yang ditetapkan dalam lembar observasi muncul sesuai dengan yang direncanakan dan melebihi $80 \%$ dari jumlah diskriptor.

\section{HASIL DAN PEMBAHASAN}

Deskripsi Hasil Penelitian Perbaikan Pembelajaran, berdasarkan data hasil tugas harian yang dilaksanakan pada hari jumat 15 dan 24 Agusutus 2018 diketahui bahwa hasil belajar matematika materi relasi dan fungsi. Penyebab rendahnya hasil belajar tersebut adalah pengelolaan kelas kurang baik, kurang perhatian pada pengawasan diskusi, kelompok diskusi sebaiknya 4 orang perkelompok, kurang menarik perhatian siswasiswa, menjelaskanya terlalu cepat, siwa belum memahami konsep relasi fungsi dengan benar. Pada siklus 1 di tahap perencanaan, perencanaan pelaksanaan penelitian tindakan kelas pada siklus I mengacu pada hasil observasi pra siklus yang dilaksanakan. Dari hasil observasi awal, permasalahan yang ditemui adalah siswa kurang menguasai materi yang diajarkan guru.

Dari permasalahan yang ada maka diputuskan untuk malakukan perbaikan pembelajaran dalam meningkatkan hasil belajar persamaan garis lurus. Untuk melaksanakan kegiatan tersebut peneliti melakukan perencanaan, adapun perencanaan yang dibuat yaitu: 1) Menyusun rencana pelaksanaan pembelajaran (RPP) sesuai dengan 
metode ekspositori dan berdasarkan pada kurikulum yang berlaku, 2) Menyusun dan mempersiapkan lembar observasi mengenai proses pembelajaran yang dilaksanakan. 3) Menyusun soal post test yang akan digunakan untuk mengukur peningkatan hasil belajar matematika siswa.

Pada tahap pelaksanaan, penelitian pada siklus I dilaksanakan pada hari Senin tanggal 31 Agustus 2018, guru menjelaskan materi persamaan garis lurus dengan memperhatikan metode ekspositori sesuai dengan Rencana perbaikan. Guru sudah menyiapkan rencana pembelajaran yang akan digunakan pada saat proses pembelajaran. Kegiatan awal guru memberikan apersepsi melalui demonstrasi pembelajaran yang akan dilakukan dan menginformasikan tujuan pembelajarn hari ini Selain itu guru juga memotivasi siswa untuk aktif mengikuti proses pembelajaran. Kegiatan inti guru menjelaskan materi kepada siswa tentang persamaan garis lurus kemudian guna melibatkan siswa dan menumbuhkan keterlibatan siswa dikelas guru memberikan pertanyaan pertanyaan yang sederhana berkaitan dengan persamaan garis lurus beberapa siswa ada yang mejawab serta bertanya kepada guru.

Setelah dirasa siswa telah ikut berpastisipasi di dalam kelas maka guru melanjutkan dengan memberika korelasi antara materi dengan kehidupan sehari - hari mereka agar mereka mengetahui manfaat dan peggunaan persamaan garis lurus. Guru memberikan masalah yang mana memberikan kesempatan kepada siswa untuk menyelesaikan masalah tersebut ke depan kelas, setelah diberikan kesempatan siswa besemangat untuk unjuk kemampuan di depan kelas, dari kegiatan di atas terjadilah interkasi aktif antara guru dan siswa lalu membahas solusi dari permasalahan yang di berikan sebelumnya dan betanya kepada siswa bagi ada yang belum memahami tentang pembelajaran hari itu. Pada kegiatan akhir siswa dengan bimbingan guru menyimpulkan kegiatan pembelajaran yang sudah dilakukan. Guru juga memberikan nasihat kepada siswa untuk belajar dengan giat. Berikut ini tabel hasil belajar matematika siswa materi pecahan sederhana kompetensi dasar menyederhanakan dan mengurutkan pecahan. 
Tabel 2 Hasil belajar Matematika Siklus 1

\begin{tabular}{ccccc}
\hline No & Nilai & Frekuensi & Persentase & Tuntas / Tidak Tuntas \\
\hline 1 & 280 & 26 & $81,25 \%$ & Tuntas \\
2 & $<80$ & 6 & $18,75 \%$ & Tidak tuntas \\
\hline \multicolumn{2}{c}{ Jumlah } & 32 Siswa & $100 \%$ & \\
\hline
\end{tabular}

Sumber: Guru bidang studi matematika kelas VIII SMP Muhammadiyah 4 Palembang

Dari data di atas dapat dilihat bahwa $18,75 \%$ siswa tidak tuntas nilainya $<80$, dan $81,25 \%$ siswa tuntas nilainya $\geq 80$. Berdasarkan hasil belajar Dari hasil tindakan siklus I yang telah terurai seperti di atas maka dapat disimpulkan bahwa hasil belajar matematika materi persamaan garis kompetensi dasar, menentukan gradien, persamaan dan grafik garis lurus telah mengalami peningkatan. Pelaksanaan pembelajaran pada tindakan siklus I belum maksimum karena pada proses pembelajaran yang disampaikan oleh guru belum memenuhi sintak yang disepakati. Hasil diskusi antara guru dan dosen disepakati pembelajaran harus dilanjutkan pada tindakan siklus ke -2 .

Pada tahap observasi, pada pertemuan pertama awal pembelajaran siswa tampak antusias dalam mengikuti kegiatan pembelajaran. Antusiasme siswa tersebut meningkat dibandingkan dengan antusiasme siswa pada saat melaksanakan pra siklus. Antusiasme siswa tersebut dimulai melalui guru memotivasi siswa dengan mengugah rasa ingin tahu siswa tentang materi yang akan dipelajari serat guru menginformasikan tujuan pembelajaran hari itu. Selanjutnya, saaat guru menjelaskan materi pelajaran, siswa dengan seksama memperhatikan, dengan mejelaskan guru dapat menyempaikan langsung informasi kepada siswa dan siswa dapat bertanya secara langsung juga tentang apa yang belum mereka pahami. Setelah menjelaskan guru membangun hubungan kerjasama dengan melakukan tanya jawab kepada siswa yang mana sekali kali diselingi pertanyaan yang membuat mereka tertawa. Kemudian siswa maju ke depan kelas untuk unjuk kemampuan.

Penggunaan metode ekspositori merupakan strategi pembelajaran yang sangat efektif apabila materi pelajaran yang harus dikuasai siswa cukup luas, sementara itu waktu yang dimiliki belajar sangat terbatas. Hal tersebut dibuktikan dengan dapat tersampaikannya materi persamaan garis lurus kepada siswa dengan waktu yang cukup. Pada saat siswa di berikan masalah yang akan dikerjakannnya di depan kelas bebrapa siswa semangan untuk unjuk kemampuan di depan kelas. Namun setelah di lihat anak 
yang bersemangat menyelesaikan maslah di depan kelas hanya anak yang cerdas saja, kegiatan tersebut terlihat dari anak - anak yang lain hanya duduk melihat temannya maju ke depan. Hal ini kurang efektif karena hanya anak yang cerdas yang dominan. Selain itu juga terlihat siswa menyelesaikan masalah di depan kelas hanya mencari penyelesaiannya sendiri sendiri tidak berdiskusi dengan temanya disebelahnya membuktikan bahwa siswa belum dapat bekerja sama dengan baik karena siswa masih terdapat siswa yang belum dapat mengapresiasikan pendapatnya dengan baik. Siswa nampak kebingungan dalam menyelesaikan masalah. Dengan demikian kegiatan hanya didominasi siswa cerdas saja dan tidak ada interkasi dengan teman.

Selama proses pembelajaran siswa nampak mengikutinya dengan baik. Selain itu guru selalu mendampingi kegiatan yang dilakukan siswa, guru juga selalu membantu siswa jika mengalami kesulitan selama proses pembelajaran berlangsung. Pada akhir pembelajaran guru juga membantu siswa dalam menyimpulkan kegiatan pembelajaran yang sudah dilakukan. Guru juga memberikan klarifikasi dari masalah masalah yang dihadapi siswa selama mengikuti proses pembelajaran. Selama proses pembelajaran berlangsung siswa dapat mengikuti dari awal sampai akhir dengan baik. Hal tersebut ditunjukkan dengan siswa ikut ke dalam kegiatan tanya jawab dengan guru. Selain itu siswa mengerjakan semua tugas yang diberikan oleh guru dan mayoritas siswa dapat mengerjakan soal tersebut sampai selesai. Namun ada beberapa siswa yang belum menunjukkan kemampuannya di depan kelas dan kurang adanya interaksi antar teman serta masih ada 16 anak yang hasil belajarnya rendah.

Pada tahap refleksi, dalam hasil pengamatan pada siklus I ini kegiatan refleksi difokuskan pada temuan masalah pada siklus I, dan perancangan perbaikan yang akan dilaksanakan pada siklus II. Dalam tahap ini menentukan masalah-masalah yang harus diperbaiki dalam siklus selanjutnya dan menyusun rancangan tindakan yang berupa desain pembelajaran dengan metode ekspositori.

Di siklus II, pada tahap perencanaan pembelajaran pada siklus II materi yang disampaikan kepada siswa adalah menetukan persamaan garis jika diketahui gradien dan titik koordinat. Pada mata pelajaran matematika guru menjelaskan tentang gradien dan bagaiman menentukan persamaan garis jika diketahui dua titik dan gradien. Pada siklus ini siswa dituntut untuk berperan aktif dalam mengikuti proses pembelajaran dan guru sebagai fasilitator. Adapun perencanaan yang dibuat yaitu: 1) Menyusun rencana pelaksanaan pembelajaran (RPP) sesuai dengan materi yang akan disampaikan sesuai dan 
berdasarkan pada kurikulum yang berlaku, 2) Menyusun dan mempersiapkan lembar observasi mengenai proses pembelajaran yang dilaksanakan menggunakan metode ekspositori, dan 3) Menyusun soal post test yang akan digunakan untuk mengukur peningkatan hasil belajar matematika siswa.

Pada tahap pelaksanaan, kegiatan awal guru memberikan apersepsi melalui materi yang telah di pelajari pada siklus I. Selain itu guru juga memotivasi siswa untuk aktif mengikuti proses pembelajaran. Pada kegiatan inti dari kegiatan siklus II ini sama seperti siklus I guru memberikan penjelasna tentang tentang gradien dan bagaiman menentukan persamaan garis jika diketahui dua titik dan gradien. Kemudian guru memberikan stimulus dengan tanya jawab kepada siswa. Kemudian setelah diarasa siswa telah tertarik belajar dengan tanya jawab maka guru memeberikan masalah yang mana mereka mendiskusikan terlebih dahulu dengan kelompoknya kemudian beberpa anggota kelompok menuliskan jawaban dan teman yang lain mengemukakkan di depan kelas, dengan dibuatnya duduk secara berkelomok siswa bisa saling berintreksi dan perwakilan teman setia kelompok tidak didominasi lagi dengan siswa yanng cerdas.

Kegiatan akhir dari siklus II adalah siswa dibimbing guru untuk dapat menyimpulkan kegiatan pembelajaran yang sudah dilakukan. Selama proses pembelajaran dari awal sampai akhir guru selalu membimbing siswa ketika mengalami kesulitan. selain itu siswa juga terlihat aktif dalam mengikuti proses pembelajaran. Kemudian siswa diminta untuk mengerjakan soal post test. Pada saat sebelum mengerjakan tugas guru menjelaskan langkah-langkah dalam mengerjakan tugas dengan memberikan contoh soal dan penyelesaiannya. Pada kegiatan akhir siswa dengan bimbingan guru menyimpulkan kegiatan pembelajaran yang sudah dilakukan. Guru juga memberikan nasihat kepada siswa untuk belajar dengan giat.

Tabel 3. Hasil belajar Matematika Siklus 2

\begin{tabular}{ccccc}
\hline No & Nilai & Frekuensi & Persentase & Tuntas/Tidak Tuntas \\
\hline 1 & $\geq 80$ & 28 & $87,50 \%$ & Tuntas \\
2 & $<80$ & 4 & $12,50 \%$ & Tidak tuntas \\
\hline \multicolumn{2}{c}{ Jumlah } & 32 Siswa & $100 \%$ & \\
\hline
\end{tabular}


Dari data dapat dilihat bahwa $12,5 \%$ siswa tidak tuntas nilainya $<80$; dan $87,50 \%$ siswa tuntas nilainya $\geq 80$. Berdasarkan hasil belajar matematika materi persamaan garis jika diketahui gradfien dan titik dari hasil post test di siklus 2 hasilnya tuntas. Berdasarkan hasil tindakan siklus 2 yang telah teurai seperti di atas maka dapat disimpulkan bahwa hasil belajar matematika materi persamaan garis kompetensi dasar menentukan gradien, persamaan dan grafik garis lurus. Peningkatan tersebut sudah memenuhi target yang ingin dicapai. Dengan demikian penelitian sudah tidak dilanjutkan atau berakhir. Penelitian ini berakhir dengan meningkatnya hasil belajar matematika materi persamaan garis pada kelas VIII SMP Muhammadiyah 4 Palembang.

Hasil diskusi dan observasi menggunakan model ekpositori oleh guru dan dosen sekolah diper oleh hasil sebagai berikut: pada pertemuan pertama awal pembelajaran siswa tampak antusias dalam mengikuti kegiatan pembelajaran. Pada saat guru mengulang materi pada siklus I siswa tampak fokus mendengarkan penjelasan dari guru. Dalam menjelaskan materi gradien dan persamaan garis kompetensi dasar menentukan gradien, persamaan dan grafik garis lurus. Guru menjelaskan secara jelas dengan disertai memberikan contoh pada setiap langkahnya. Sehingga siswa tampak lebih fokus dalam melakukan. Selajutnya guru melaukan kegiatan tanya jawab guna menarik perhatian siswa dan mengetahui kemampuan yang telah diterima siswa. Selama proses pembelajaran guru selalu mendampingi kegiatan yang dilakukan siswa. Selain itu guru juga selalu membantu siswa jika mengalami kesulitan selama proses pembelajaran berlangsung.

Pada akhir pembelajaran guru juga membantu siswa dalam menyimpulkan kegiatan pembelajaran yang sudah dilakukan. Guru juga memberikan klarifikasi dari masalahmasalah yang dihadapi siswa selama mengikuti proses pembelajaran. Pada saat mengerjakan soal latihan siswa dapat mengerjakan dengan baik. Siswa mengerjakan secara individu. Selain itu siswa juga tidak tampak mengalami kesulitan. hal tersebut dibuktikan dengan siswa dapat mengerjakan soal secara tepat waktu. Dalam tahap ini sudah tidak ditemukan masalah-masalah yang utama dan harus diperbaiki dalam siklus selanjutnya. sehingga dapat disimpulkan bahwa penelitian ini berhenti pada siklus II dan tidak perlu dilanjutkan. Oleh karenanya hasil belajar matematika siswa kelas VII SMP Muhammadiyah 4 Palembang materi persamaan garis lurus telah meningkat. 


\section{SIMPULAN}

Berdasarkan pelaksanaan penelitan yang dilakukan di kelas VIII SMP dapat disimpulkan bahwa: 1) dengan mengoptimalkan metode ekspositori dapat meningkatkan hasil belajar siswa kelas VIII SMP dari rata- rata ketuntasan materi relasi dan fungsi sebesar $73 \%$ belum mencapai ketuntasan nilai $\geq 80$, menjadi $81,25 \%$ tuntas pada siklus I dan, pada siklus II meningkat menjadi $87.50 \%$ siswa tuntas. 2) Upaya untuk meningkatkan hasil belajar menggunakan metode ekspositori adalah: (1)Pada taraf persiapan diberikan motivasi, kemukakan tujuan yang harus dicapai, kuasai pengelolaan kelas, (2) Guru harus memikirkan dalam penyajian ini adalah bagaimana agar materi pelajaran dapat dengan mudah ditangkap dan dipahami oleh siswa, (3) Guru menghubungkan materi pelajaran dengan pengalaman siswa atau dengan hal-hal lain yang memungkinkan siswa dapat menangkap keterkaitannya dalam struktur pengetahuan yang telah dimilikinya, (4) Menyimpulkan untuk memahami inti (core) dari materi pelajaran yang telah disajikan, (5) mengaplikasikan dengan membuat tugas yang relevan dengan materi yang telah disajikan, dengan memberikan tes yang sesuai dengan materi pelajaran yang telah disajikan. 


\section{DAFTAR PUSTAKA}

Arikunto, S. (2013). Prosedur Penelitian Suatu Pendekatan Praktik. Jakarta: Rineka Cipta.

Atriyanto, B., \& Sulistiyo, E. (2014). Pengaruh Strategi Pembelajaran Ekspositori Terhadap Hasil Belajar Siswa pada Mata Diklat Memperbaiki Compact Cassete Recorder Kelas XI TAV di SMA Negeri 2 Surabaya. Jurnal Pendidikan Teknik Elektro, 3 (2), 09-13.

Kieran, C. (2004). Algebraic Thinking in the Early Grades: What Is It? The Mathematics Educator , 8(1), 29-151.

Kunandar, K. (2011). Langkah Mudah Penelitian Tindakan Kelas Sebagai Pengembangan Profesi Guru. Jakarta: Rajawali Pers.

Sunardi, S. (2013). Penilaian Pembelajaran (Asesmen). Palembang: Tunas Gemilang Pers.

Suryadi, D. (2013). Didactical Design Research (DDR) dalam Pengembangan Pembelajaran Mtaematika. Prosiding Seminar Nasional Matematika dan Pendidikan Matematika. 1, pp. 3-12. Bandung: STKIP Siliwangi Bandung. 